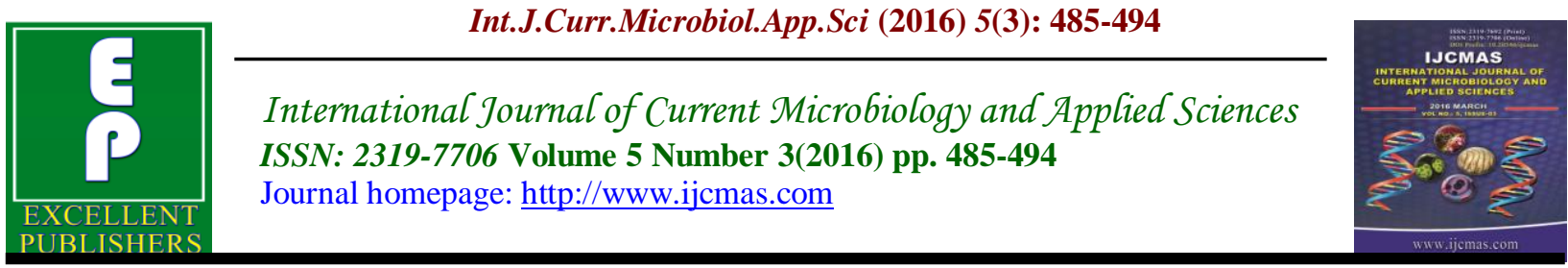

Original Research Article

http://dx.doi.org/10.20546/ijcmas.2016.503.057

\title{
Comparative analysis of phytochemical constituents and antibacterial activity of leaf, seed and root extract of Cajanus cajan (L.) Mill sp
}

\author{
R. Raveena Devi*, R.Premalatha and A.Saranya \\ Department of Microbiology and Biochemistry, Nadar Saraswathi College of Arts and Science, \\ Theni - 625 531, Tamil Nadu, India \\ *Corresponding author
}

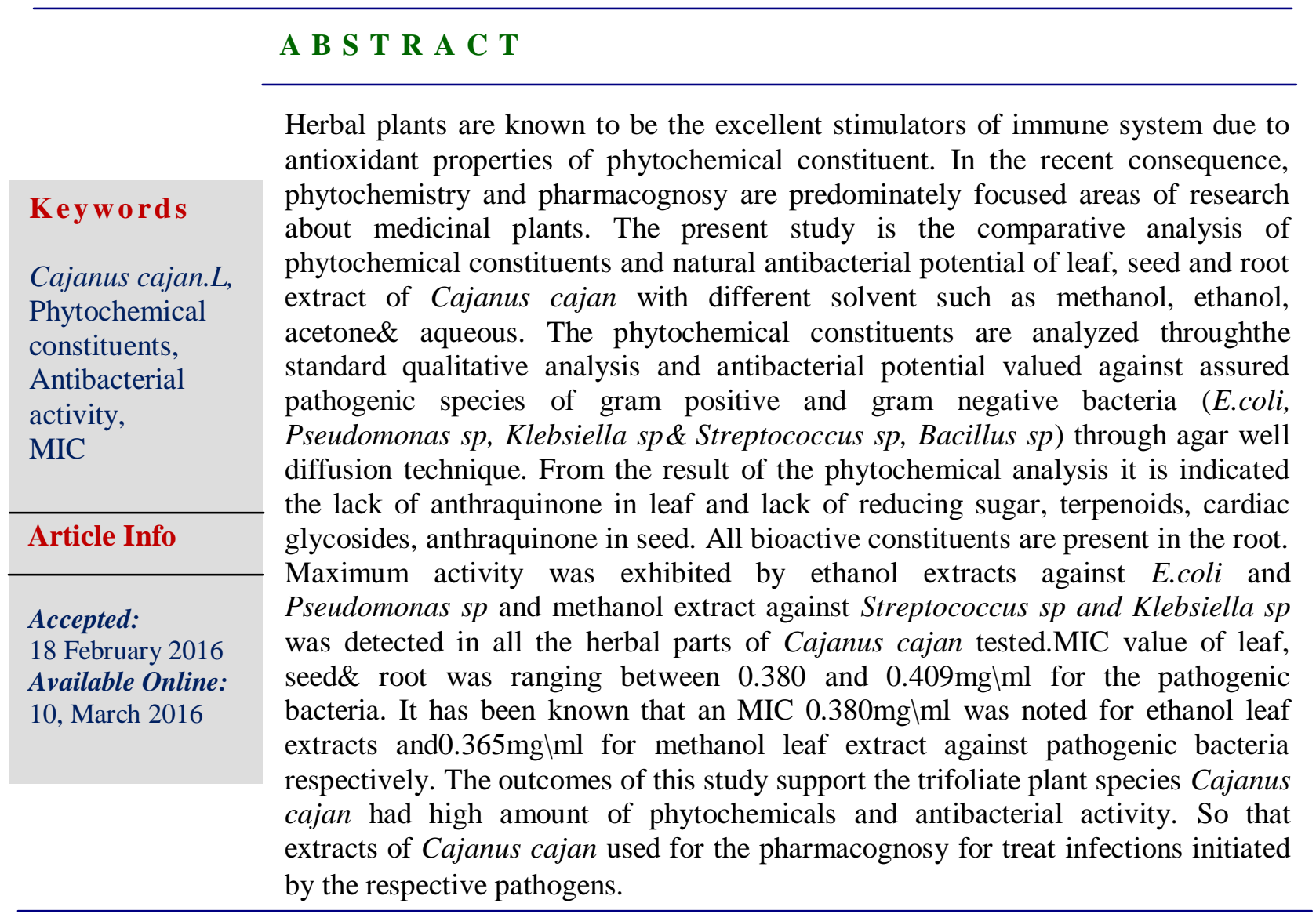

\section{Introduction}

Herbal plants have been recently popularized in modern medicine, since many therapeutically important compounds are derived from them (Gosh et al., 2006). Herbs are staging a comeback and herbal "renaissance" is happening all over the globe. Mankind has been using plants as therapeutic agents for thousands of years and continues to rely on them for healthcare (Ahsan et al., 2009). More than $30 \%$ of the 
entire plant species, at one time or other was used for medicinal purposes. Herbal plant based drugs have been in use against various infections (Ahmad et al., 2009).

Herbal plants are considered into bio resources of drug. A number of excitingproducts have been found with the use of a combination of plant extracts to treat diseases. The antimicrobial properties of plants have been studied by a number of investigators worldwide through biological development of plants extracts is vital to ensure their efficacy and safety. These factors are of importance if plant extract are to be accepted as valid medical agents for the treatment of infectious diseases especially for the multi-drug resistance bacteria.

Trifoliate plants i.e., plants bearing three leaflets at each node produce Flavonoids and isoflavanoid compounds (phytochemicals) (Dogra 2009).Decoctions of the leaves were believed to have chemical compounds which are active against pathogenic microorganism. More people have continued to use these herbs for their treatment of different pathogenic infection in the absence of adequate toxicity data and proper understanding of their medicinal properties. Traditional medicine practitioners consider that these herbs are non-toxic even though there is no scientific backing to support this claim(Oyewole et al., 2010).Quality evolution of plant resources and herbal preparation is a important requirement of industry and other organization dealing with Ayurveda and herbal products(Arsul et al., 2011).

These herbs possesses a good amount of bioactive compounds that make them effective as a potent medicinal plant in this regard,we have chosen Cajuns cajan .which is highly grown in Andrapradesh. There is a lot of information, data and collected works but there is very limited work testified on the present direction.

Pigeon pea (Cajuns Cajan L.), a diploid legume crop species is a member of the tribe phaseoleae. ). Pigeon pea(Cajuns cajan), which belongs to the legume family is a multipurpose, hardy grain legume crop grown by many developing countries in semi-arid tropics and sub tropics $(\mathrm{Zu}$ et al., 2006)pigeon pea occupies an important aspect in human nutrition as a source of dietary protein in several countries (Abdelati et al., 2009).

The leaves are traditionally used as stringent, diuretic, laxative, antiinflammatory and oral ulcers. The leaf extracts display defending effects against alcohol induced liver damage and hypo toxic-ischemic brain damage (kundu et al., 2008) theresearch on chemical elements indicated that the pigeon pea leaves are rich in flavonoids, stilbenes which are considered to be responsible for the beneficiaries of leaves on human health. (zu et al.,2006)

The extracts or components of pigeon pea are mostly used all over the world. For cure the diabetes, dysentery and hepatitis (Grover et al., 2002) currently days, these leaves are used for the treatment of injuries, naphtha, ulcers and malaria as well as diet-induced hypercholesterolemiaetc. (Aiyeloja and Bello, 2006,Luo et al., 2008).

Cajanus cajan seeds are now well-thoughtout as a non -conventional feed substance in poultry feeding and as a valuable protein feed resource. The seeds of the plant are also claimed to cure gingivitis, stomatitis (Ganeshan, 2008). Cajanus cajan roots are considered anthelmintic, expectorant, febrifuge, sedative, vulnerary (Kong, 2010). My research has been planned to examine 
the comparative analysis of phytochemical constituents, natural antibacterial potential of the various part of the Cajanus cajan plant extract.

\section{Materials and Methods}

\section{Collection and Processing of Plant Materials}

The fresh leaves, roots and seeds of Cajuns Cajan $L$. were simultaneously collected from local area of Theni district. Fresh parts of the plants were Identified and authenticated prior to phytochemical analysis. The leaves, Seed\& roots were rinsed thrice with distilled water followed by double distilled water to remove the dust and other contaminants thendried for about 2-3 weeks at room temperature under shade conditions. The dried leaves, seeds, roots were ground separately into powdery form using an electric grinder, then stored and labeled in sterilized containers.

\section{Preparation of Plant Extracts}

For phytochemical analysis, the extracts were prepared by taking $2 \mathrm{gms}$ of each dried powder into separate $100 \mathrm{ml}$ conical flask and $50 \mathrm{ml}$ of each solvent (Aqueous, Methanol, ethanol and Acetone) was added. The conical flasks were plugged with cotton plugs, labeled and allowed to stand for 1-2 hrs. And then filtered using what man No.1 filter paper. Thus, the filtrates obtained were used as test solutions.

\section{Qualitative Analysis of Phytochemical Screening}

The plant extracts were tested for the presence of bioactive compounds such as alkaloids, anthocyanin and cardiac glycosides, coumarins, reducing sugars, flavonoids, phenols, quinines saponins,
Steroids, tannins, terpenoids by standard method (Yadav et al.,2011).

\section{Test for Flavonoids}

\section{Ferric Chloride Test}

Few drops of $\mathrm{FeCl} 3$ solution was added to the test solution. Blackish precipitate indicates the presence of flavonoids.

\section{Alkaline Reagent Test}

The test solution was treated with sodium hydroxide solution. Yellow to red colour indicates the presence of flavonoids.

Qualitative Analysis of Saponins (Foam Test)

$5 \mathrm{ml}$ of plant extracts were mixed with equal volume of distilled water and mixed vigorously for 3 to $5 \mathrm{~min}$ gives intense stable foam development. In addition of $3 \mathrm{ml}$ of olive oil mixed vigorously, observed the development of emulsion.

\section{Qualitative Analysis of Glycoside by Keller- Killani Test Method}

To $0.5 \mathrm{ml}$ of the plant extract, $2 \mathrm{ml}$ of glacial acetic acid and few drops of 5\%ferric chloride were added along the side of the test tube. Formation of brown ring at the interface indicates the presence of cardiac glycosides.

\section{Qualitative Analysis of Steroids}

Plant extracts mixed in $2 \mathrm{ml}$ of chloroform and Conc. $\mathrm{H}_{2} \mathrm{SO}_{4}$ were added gently, which leads to the development of red colour in the lower chloroform layer indicating the presence of steroid, and was further confirmed with addition of acetic acid which develops the greenish colour formation. 
Qualitative Analysis of Terpenoids by Salkowski Test Method

To $0.5 \mathrm{ml}$ of the leaf extract, $2 \mathrm{ml}$ of chloroform and $0.5 \mathrm{ml}$ of concentrated sulphuric acid was added carefully. Formation of reddish brown coloration at the interface indicates the presence of terpenoids.

\section{Qualitative Analysis of Alkaloids}

About $1 \mathrm{ml}$ of plant extract was dissolved in $5 \% \mathrm{HCl}$, filtered and tested with Dragendorrf's reagent and Mayer's reagent separately. Any precipitate or turbidity with the reagent suggests the presence of alkaloids.

\section{Qualitative Analysis of Anthocyanin and Betacyanin}

About $2 \mathrm{ml}$ of test extract was added with $1 \mathrm{ml}$ of $2 \mathrm{~N} \mathrm{NaOH}$ and heated for $5 \mathrm{~min}$ at $100^{\circ} \mathrm{C}$ Formation of bluish green colour indicates the presence of anthocyanin and formation of yellow colour indicates the presence of beta cyanine

\section{Qualitative Analysis of Coumarins}

$5 \mathrm{ml}$ of the moistened solvent plant extract was taken in a test tube. The mouth of the tube was covered with filter paper treated with $1 \mathrm{~N} \mathrm{NaOH}$ solution. Test tube was placed for few minutes in boiling water and then the filter paper was removed and examined under the UV light for yellow fluorescence indicated the presence of coumarins.

\section{Qualitative Analysis of Phenols and Tannins}

Plant extract was mixed with $2 \mathrm{ml}$ of $2 \%$ solution of $\mathrm{FeCl}_{3}$. A blue-green or black coloration indicated the presence of phenols and tannins.

\section{Qualitative Analysis of Reducing Sugars}

$1 \mathrm{ml}$ of the extract was added with $2 \mathrm{ml}$ of Fehling's reagent and $3 \mathrm{ml}$ of water. It was then boiled for 2 minutes.

\section{Antibacterial Assay}

\section{Test Organisms}

Gram negative bacterial strain Escherichia coli, pseudomonas sp, Klebsiella $s p$ and gram positive strain Streptococcus $s p$, Bacillus $s p$ were used as a present study. They were obtained from laboratory of Department of Microbiology, Nadar Saraswathi College. They were maintained at $4^{\circ} \mathrm{C}$ on the slants of nutrient agar medium for further use. The isolates were identified by standard biochemical method.

\section{Well Diffusion Method}

Antimicrobial activity was performed using the well-diffusion method (NCCLS 1993). The plant extracts (leaf, seed root) were tested on Mullen Hinton agar plates to detect the presence of antibacterial activity.

Bacterial suspensions for each of the tested organism were prepared in $9 \mathrm{ml}$ sterile nutrient broth and were incubated at $37^{\circ} \mathrm{c}$ for $18 \mathrm{hrs}$ to obtain a turbidity of 0.5macfarland.each bacterial suspension corresponding were spread on the surface of Mullen Hinton agar plates with sterile cotton swab and kept to dry. The antimicrobial assay was achieved with agar diffusion technique, consequently five equally distant $6 \mathrm{~mm}$ wells were made on the inoculated Mullen Hinton agar plates with the help of a sterile cork borer. Each well was loaded with $50 \mu 1$ of different solvent plant extract respectively using a micropipette, the extract was allowed to diffuse for 30minutes at room temperature and the loaded plates were 
then incubated at $37^{\circ} \mathrm{C}$ for 18 to $24 \mathrm{hrs}$. Standard streptomycin used as a control. Appearance of a zone indicated the presence of antibacterial of the plant extract being tested against the bacterial isolates.

\section{Determination Minimum Inhibitory Concentration}

The MIC of the extracts was determined according to the macro broth dilution technique (NCCLS 2000). From the prepared plant extracts $25 \mu 1,50 \mu \mathrm{l}, 75 \mu \mathrm{l}$, and $100 \mu \mathrm{l}$, was taken. It is added to the series of test tubes containing $10 \mathrm{ml}$ of nutrient broth. About $0.1 \mathrm{ml}$ of microbial culture is also added to each and every tube. The tubes were incubated at $37^{\circ} \mathrm{C}$. After overnight or 48 hours the turbidity is measured using spectrophotometer in terms of optical density at 540nm.

\section{Results and Discussion}

The phytochemical components\& antibacterial activity Cajuns Cajan (leaf, seed, and root) extracts was examined in the present study. The herbal products today symbolize safety in contrast to the synthetics that are regarded as unsafe to humans and environment. Although herbs had been priced for their medicinal, flavouring and aromatic qualities for centuries, the synthetic products of the modern age surpassed their important, for a while. However, the blind dependence on synthetics is over and people are returning to the naturals with a hope of safety and security.

From the result of my study show that predominant phytochemical constituent's present in the Cajanus cajan leaf, seed \& root extract of different solvent. Comparative screening indicated that lack of anthraquinone in leaf and lack of reducing sugar, terpenoids, cardiac glycosides, anthraquinone in seed. Almost all phytochemical constituents are present in the root extract.

The three parts of the Cajuns Cajan L. extracts efficacy were screened against gram negative E.coli, pseudomonas sp, Klebsiella $s p$, and gram positive Streptococcus $s p$, Bacillus $s p$ isolates. To measure the antibacterial activities through well diffusion assay. And zone of inhibition was measured in millimetre. Maximum activity was exhibited by ethanol extracts against E.coli and pseudomonas sp and methanol extract against Streptococcus sp and Klebsiella $s p$ was observed in all the plant parts of Cajanus cajan tested. Comparative antibacterial potential indicated that leaf extract exhibit the maximum activity against pathogenic bacteria. Compare to different solvent, acetone extract showed least activity. Along with the three tested seed extract showed the least activity against the bacteria (table2-6).

Minimum inhibitory concentration of leaf, seed\& root was observed between the 0.383 and $0.409 \mathrm{mg} \backslash \mathrm{ml}$ for the pathogenic bacteria. It has been identified that an MIC $0.383 \mathrm{mg} \backslash \mathrm{ml}$ was recorded for ethanol leaf extracts and $0.365 \mathrm{mg} \backslash \mathrm{ml}$ for methanol leaf extract against pathogenic bacteria respectively (table7).

From my study high amount of phytochemicals obtained from Cajanus cajan (leaf, seed and root). So, Cajanus cajan contains good source of phytochemicals (table-1).

The result of the study is in support with the reports of K.K Harris et al., (2014). They have stated that high amount of phytochemicals present in leaf, seed, and shoot of Cajanus cajan L. 
Table.1 Phytochemical Constituents of Cajanus Cajan

\begin{tabular}{|l|l|l|l|l|l|l|l|l|l|l|l|l|}
\hline Compounds & \multicolumn{3}{|l|}{ Methanol extract } & \multicolumn{3}{l|}{ Ethanol extract } & \multicolumn{3}{|l|}{ Acetone extract } & \multicolumn{3}{|l|}{ Aqueous extract } \\
\hline Leaf, seed and root & $1^{*}$ & $2^{\circ}$ & $3^{*}$ & $1^{*}$ & $2^{\circ}$ & $3^{*}$ & $1^{*}$ & $2^{\circ}$ & $3^{*}$ & $1^{*}$ & $2^{\circ}$ & $3^{*}$ \\
\hline Alkaloids & $\mathrm{P}$ & $\mathrm{P}$ & $\mathrm{P}$ & $\mathrm{P}$ & $\mathrm{P}$ & $\mathrm{P}$ & $\mathrm{P}$ & $\mathrm{P}$ & $\mathrm{P}$ & $\mathrm{P}$ & $\mathrm{P}$ & $\mathrm{P}$ \\
\hline Flavonoids & $\mathrm{P}$ & $\mathrm{P}$ & $\mathrm{P}$ & $\mathrm{P}$ & $\mathrm{P}$ & $\mathrm{P}$ & $\mathrm{P}$ & $\mathrm{P}$ & $\mathrm{P}$ & $\mathrm{P}$ & $\mathrm{P}$ & $\mathrm{P}$ \\
\hline Tannins & $\mathrm{P}$ & $\mathrm{P}$ & $\mathrm{P}$ & $\mathrm{P}$ & $\mathrm{P}$ & $\mathrm{P}$ & $\mathrm{P}$ & $\mathrm{P}$ & $\mathrm{P}$ & $\mathrm{P}$ & $\mathrm{P}$ & $\mathrm{P}$ \\
\hline Terpenoids & $\mathrm{A}$ & $\mathrm{A}$ & $\mathrm{P}$ & $\mathrm{P}$ & $\mathrm{A}$ & $\mathrm{P}$ & $\mathrm{A}$ & $\mathrm{A}$ & $\mathrm{P}$ & $\mathrm{A}$ & $\mathrm{A}$ & $\mathrm{P}$ \\
\hline Phenol & $\mathrm{P}$ & $\mathrm{P}$ & $\mathrm{P}$ & $\mathrm{P}$ & $\mathrm{P}$ & $\mathrm{P}$ & $\mathrm{P}$ & $\mathrm{P}$ & $\mathrm{P}$ & $\mathrm{P}$ & $\mathrm{P}$ & $\mathrm{P}$ \\
\hline Steroid & $\mathrm{P}$ & $\mathrm{P}$ & $\mathrm{P}$ & $\mathrm{P}$ & $\mathrm{P}$ & $\mathrm{P}$ & $\mathrm{P}$ & $\mathrm{P}$ & $\mathrm{P}$ & $\mathrm{P}$ & $\mathrm{P}$ & $\mathrm{P}$ \\
\hline Cardiac glycosides & $\mathrm{P}$ & $\mathrm{P}$ & $\mathrm{P}$ & $\mathrm{P}$ & $\mathrm{A}$ & $\mathrm{P}$ & $\mathrm{P}$ & $\mathrm{P}$ & $\mathrm{P}$ & $\mathrm{P}$ & $\mathrm{A}$ & $\mathrm{P}$ \\
\hline Anthraquinone & $\mathrm{A}$ & $\mathrm{A}$ & $\mathrm{P}$ & $\mathrm{A}$ & $\mathrm{A}$ & $\mathrm{P}$ & $\mathrm{A}$ & $\mathrm{A}$ & $\mathrm{P}$ & $\mathrm{P}$ & $\mathrm{P}$ & $\mathrm{A}$ \\
\hline Coumarins & $\mathrm{P}$ & $\mathrm{A}$ & $\mathrm{P}$ & $\mathrm{P}$ & $\mathrm{A}$ & $\mathrm{P}$ & $\mathrm{P}$ & $\mathrm{A}$ & $\mathrm{P}$ & $\mathrm{P}$ & $\mathrm{A}$ & $\mathrm{P}$ \\
\hline Reducing sugar & $\mathrm{P}$ & $\mathrm{A}$ & $\mathrm{P}$ & $\mathrm{P}$ & $\mathrm{A}$ & $\mathrm{P}$ & $\mathrm{P}$ & $\mathrm{A}$ & $\mathrm{P}$ & $\mathrm{P}$ & $\mathrm{A}$ & $\mathrm{A}$ \\
\hline Saponins & $\mathrm{P}$ & $\mathrm{P}$ & $\mathrm{P}$ & $\mathrm{P}$ & $\mathrm{P}$ & $\mathrm{P}$ & $\mathrm{P}$ & $\mathrm{P}$ & $\mathrm{P}$ & $\mathrm{P}$ & $\mathrm{P}$ & $\mathrm{P}$ \\
\hline
\end{tabular}

$\mathrm{P}=$ PRESENCE, $\mathrm{A}=$ ABSENCE, $1^{*}=$ LEAF, $2^{\circ}=$ SEED, $3^{*}=$ ROOT

Table.2 Antibacterial Activity Against E.Coli

\begin{tabular}{|c|c|c|l|}
\hline \multicolumn{4}{|l|}{ Zone of inhibition(mm) } \\
\hline SOLVENT & LEAF & SEED & ROOT \\
\hline Methanol & 14.2 & 10.8 & 11.1 \\
\hline Ethanol & 17.2 & 12.2 & 13.4 \\
\hline Acetone & 7.1 & 6.0 & 6.1 \\
\hline Aqueous & 6.6 & 5.2 & 5.4 \\
\hline Standard & 19.6 & 20.6 & 19.2 \\
\hline
\end{tabular}

Table.3 Antibacterial Activity Against Pseudomonas $S p$

\begin{tabular}{|l|l|l|l|}
\hline \multicolumn{4}{|l|}{ Zone of inhibition(mm) } \\
\hline SOLVENT & LEAF & SEED & ROOT \\
\hline Methanol & 13.2 & 8.3 & 9.9 \\
\hline Ethanol & 17.1 & 11.1 & 12.2 \\
\hline Acetone & 4.2 & 2.9 & 4.9 \\
\hline Aqueous & 5.9 & 4.4 & 6.6 \\
\hline Standard & 20.2 & 18.2 & 19.3 \\
\hline
\end{tabular}

Table.4 Antibacterial Activities Against Streptococcus $S p$

\begin{tabular}{|l|l|l|l|}
\hline \multicolumn{4}{|l|}{ Zone of inhibition(mm) } \\
\hline SOLVENT & LEAF & SEED & ROOT \\
\hline Methanol & 18.9 & 13.6 & 14.2 \\
\hline Ethanol & 13.7 & 9.3 & 11.4 \\
\hline Acetone & 6.2 & 4.0 & 4.2 \\
\hline Aqueous & 6.7 & 3.2 & 7.5 \\
\hline Standard & 21.9 & 20.5 & 19.0 \\
\hline
\end{tabular}


Table.5 Antibacterial Activities Against Klebsiella Sp

\begin{tabular}{|l|l|l|l|}
\hline \multicolumn{4}{|l|}{ Zone of inhibition(mm) } \\
\hline SOLVENT & LEAF & SEED & ROOT \\
\hline Methanol & 17.9 & 11.1 & 12.2 \\
\hline Ethanol & 13.6 & 6.9 & 9.2 \\
\hline Acetone & 4.0 & 3.4 & 4.9 \\
\hline Aqueous & 12.6 & 9.7 & 11.2 \\
\hline Standard & 20.3 & 19.8 & 19.9 \\
\hline
\end{tabular}

Table.6 Antibacterial Activities Against Bacillus Sp

\begin{tabular}{|l|l|l|l|}
\hline \multicolumn{4}{|l|}{ Zone of inhibition(mm) } \\
\hline SOLVENT & LEAF & SEED & ROOT \\
\hline Methanol & 6.6 & 4.9 & 5.7 \\
\hline Ethanol & 7.9 & 5.2 & 6.5 \\
\hline Acetone & 5.2 & 3.4 & 3.3 \\
\hline Aqueous & 4.5 & 2.9 & 3.3 \\
\hline Standard & 19.3 & 19.8 & 21.4 \\
\hline
\end{tabular}

Table.7 Minimum Inhibitory Concentration of Cajanus cajan $L$

\begin{tabular}{|l|l|l|l|l|l|}
\hline S.NO & E.coli & Pseudomonas $s p$ & Streptococcus $s p$ & Klebsiella $s p$ & Bacillus $s p$ \\
\hline Leaf & 0.385 & 0.392 & 0.387 & 0.33 & 0.435 \\
\hline Seed & 0.391 & 0.365 & 0.389 & 0.401 & 0.395 \\
\hline Root & 0.434 & 0.408 & 0.401 & 0.398 & 0.402 \\
\hline
\end{tabular}

Figure.1 In vitro Antibacterial activity of Leaf

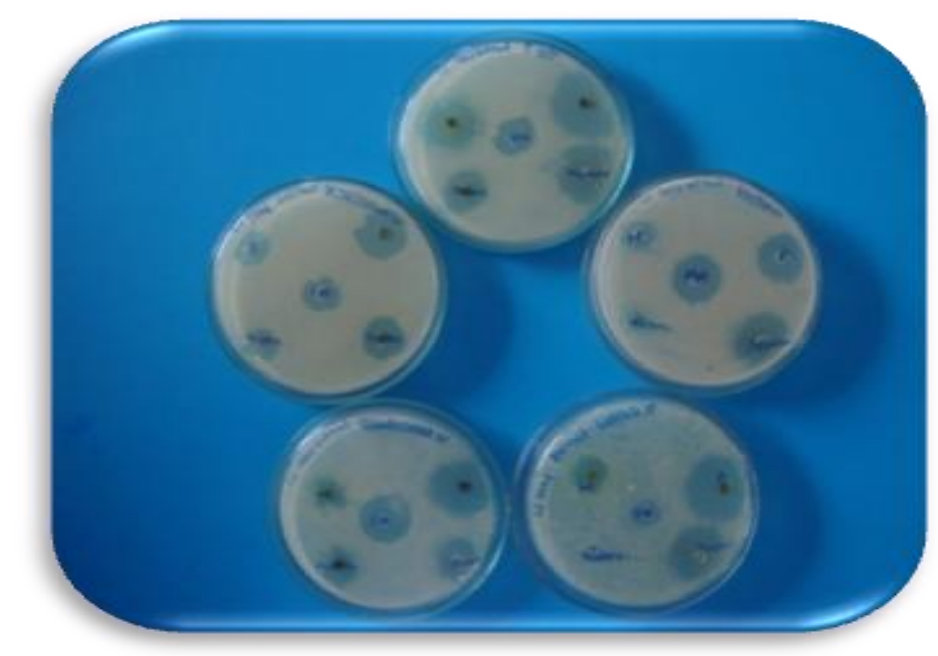


Figure.2 In vitro Antibacterial Activity of Seed

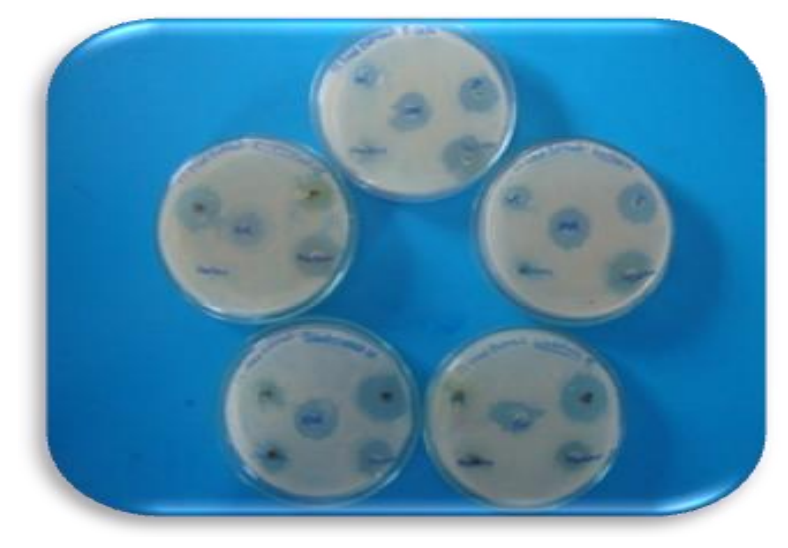

Figure.3 In vitro Antibacterial Activity of Root

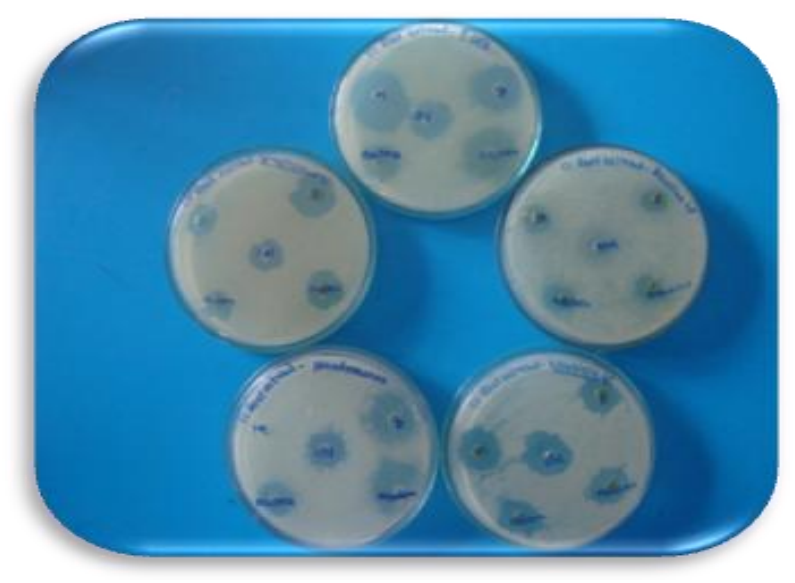

In all plant parts of Cajanus cajan. Maximum activity was exhibited bymethanol extract against Streptococcus $s p$ and Klebsiella $s p$ and ethanol extract against E.coli and pseudomonas sp tested respectively. The result of our study are in conformity with the reports of Ramaswamynanna et al., (2014). They have reported that ethanol extract of Cajanus cajan showed higher inhibitory activity against gram negative bacteria \& methanol extract showed higher inhibitory activity against gram positive bacteria.

The current study supported that the organic solvent extracts were more effective than the aqueous extracts. It has been described that the varieties of solvents have diverse solubility capacities for different phytoconstituents [Marjorie et al., 2000)].

The effect of aqueous and various organic solvent extracts of different plant parts of Cajanus cajan for antibacterial activity was determined to be compared among the tested organisms.

Based on the dosage of various solvent and aqueous extracts of Cajanus cajan inhibited the growth grampositive and gram negative bacteria tested respectively. The methanol and ethanol extracts of all the plant parts of Cajanus cajan showed more inhibitory effects in comparison to the other extracts tested. So that active ingredients are better extracted in methanol and ethanol compare 
to other extracts. It is indicate to facilitate presence of broad spectrum nature of the antimicrobial compounds present in the extracts of the methanol and ethanol. Related interpretation were also made by Prathima and Prathima Mathad [2011] who described that the ethanol extracts exhibited maximum activity on both gram positive and gram negative bacteria in Cajanus cajan.

Consequently, methanol extracts against Streptococcussp\& Klebsiella sp and ethanol extracts against E.coli and Pseudomonas spof Cajanus cajanwas studied to determine minimum inhibitory concentration. High activity indicated by low MIC value.vice versa

It can be concluded that different extracts of leaf, seed\& root of the Cajanus cajan are a great potential source of antibacterial compounds. The proximate analysis reveals high amount of phytochemical constituents. It is concluded from the result that Cajanus cajan (leaf, seed \& root) could be used in formulation of new antimicrobial drugs of natural basis.

\section{Acknowledgement}

The project was supported by laboratory of Department of Microbiology \& Biochemistry in Nadar Saraswathi College of Arts \& Science, Theni. I thank the Management, Principal, Head of the Department, Faculty members for their guidance and support.

\section{References}

Abdelati KH, Mohammed HAR and Ahmed ME, 2009.Influence Of Feeding Processed Pigeon Pea (Cajanus cajan) Seeds on Broiler Performance. IntJ.Poult Sci., 8(10):971-975.

Ahmad M, Qureshi R ,Arshad M, Khan MA and Zafar M,(2009).Traditional Herbal Medicines Used For The Treatment Of Diabetes From District Attack(Pakistan).Pak.J.Bot,41(6):2777 -2782 .

Ahsan, R. and M. Islam, 2009.In Vitro Antibacterial Screening and Toxicological Study of Some Useful Plants (Cajanus cajan). European Journal Science Research, 41: 227-32.

Dogra P, (2009), Study Of Antibacterial And Anticancer Activity Of Selected Trifoliate Plants. Bio frontiers, 1(2):48.

Ganeshan S. 2008. Traditional Oral Care Medicinal Plants Survey of Tamil Nadu. Natural Product Radiance 7, 166-172.

Ghosh A, Sarkar K and Sill PC, (2006).Protective Effect Of A 43KD Protein from the Leaves of the Herb, CajanusIndicus L .On Chloroform Induced Hepatic -Disorder. Journal of Biochemistry and Molecular Biology, 39(2):197-207.

Grover, J. K., Yadav, S. and Vats, V. J. 2002. Medicinal Plants of India with Ant diabetic Potential. J. Ethnopharmacol. 81: 81-100.

Hussein MA, Gorsi MS (2004) Antimicrobial Activity of Nerium Oleander Linn.

Kong Y, Fu YJ, Zu YG, Chang FR, Chen $\mathrm{YH}$, Liu XL, et al. Cajanuslactone a new coumarin with anti-bacterial activity from pigeon pea leaves. Food Chem. 2010; 121:1150-5.

Kundu R, Dasgupta S, Biswas A, Bhattacharya S, Cajanus cajan Linn. (Leguminosae) Prevents AlcoholInduce Rat Liver Damage and Augments Cytoprotective Function, J Ethnopharmacol, 118, 2008, 440-447.

Liu, R.H. Potential Synergy of Phytochemicals in Cancer Prevention: Mechanism of Action. J.Nutr. 
2004:134(12):3479s-85s.

Madhuri S, Pandey G. some anticancer medicinal plants of foreign origin. Current science, 2009; 96:779-783.

NCCLS methods for dilution antimicrobial susceptibility, Tests for Bacteria That grow aerobically; Approved standard fifth generation. NCCLS document M7-A5, NCCLS: Wayne, PA, USA, 2000.

NCCLS, Performance standards for antimicrobial disc susceptibility tests. Approved standard NCCLS publication M2-A5, Villanova, PA, USA, 1993.

Oyewole OI, Oweseni AA and Fabora
EO,(2010).Studies On Medicinal and Toxicological Properties Of Cajanus cajan, Ricinus communis, and Thymus Vulgaris Leaf Extracts. J.Med.Plant. Res,4(19):2004-2008.

Yadav, R.N.S and Agarwal, M. Phytochemical analysis of some medicinal plants.J.phytol.2011; 3(12); 10-14.

$\mathrm{Zu} \mathrm{Y,} \mathrm{Fu} \mathrm{Y,} \mathrm{Liu} \mathrm{W,} \mathrm{and} \mathrm{Kong} \mathrm{Y,}$ (2006).Simultaneous Determination Of Four Flavonoid's In Pigeon Pea (Cajanus cajan (L) Millsp.Leaves Using Rp-Lc-Dad.

\section{How to cite this article:}

Raveena Devi, R., R.Premalatha and Saranya, A. 2016. Comparative analysis of phytochemical constituents and antibacterial activity of leaf, seed and root extract of Cajanus cajan (L.) Mill sp Int.J.Curr.Microbiol.App.Sci. 5(3): 485-494. doi: http://dx.doi.org/10.20546/ijcmas.2016.503.057 